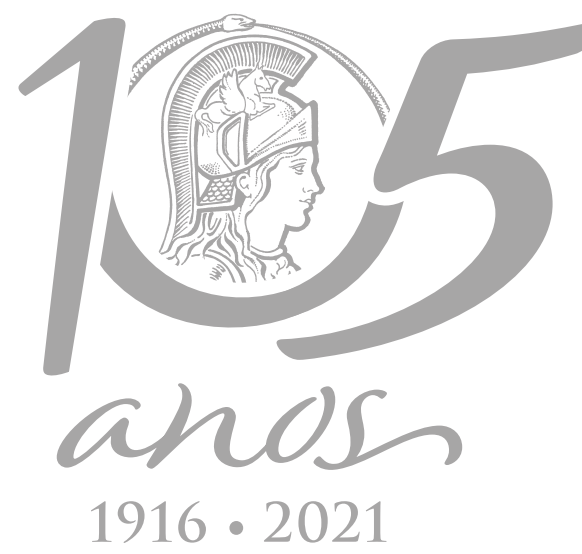

\title{
MICROBIOLOGY
}

\section{Evaluation of the influence of chemical and physical factors on mixtures of fungal and plant lipases}

\author{
CLARISSA H. OKINO-DELGADO, MILENE STEFANI PEREIRA, DÉBORA Z. DO PRADO \\ \& LUCIANA FRANCISCO FLEURI
}

\begin{abstract}
Lipases are biocatalysts that may have distinct biochemical characteristics depending on the source. The combination of lipases from different sources with complementary characteristics is a viable strategy for increasing the enzymatic activity. In this study, fungal (Aspergillus niger 01 - CBMAI 2084) and plant (orange frit - orange peel fragment) lipases were analyzed separately and together in different concentrations. In addition, we evaluated the influence of organic solvents and ultrasonic effect on lipase activity, as well as substrate specificity [p-nitrophenyl butyrate (pNPB), p-nitrophenyllaurate ( $\mathrm{pNPL}$ ) and $\mathrm{p}$-nitrophenyl-palmitate ( $\mathrm{p}$-NPP)] and enzymatic immobilization in different supports (celite, silica, aluminum oxide, Lewatti, calcium alginate and gelatin). Increased enzyme activity was observed in formulations with higher concentration of fungal extract. The combination of 50\% fungal extract and $25 \%$ plant extract increased about 55\% lipase activity, showed the highest absolute lipase activity among all combinations and was selected for the following study. Plant extract showed the highest lipase activity in the hydrolysis of $\mathrm{p}-\mathrm{NPB}$ and $\mathrm{p}-\mathrm{NPL}$, however, fungal extract showed the highest hydrolytic activity on P-NPP. When applied to synthetic substrates, the combination of plant and fungal extracts showed less stability and activity in synthetic substrates than isolated extracts, however lipase activity increased after 20s on ultrasound bath. Regarding to immobilization techniques, the adsorption on silica was the most efficient for all lipase extracts.
\end{abstract}

Key words: adsorption, food industry, fungal lipase, orange waste lipase, silica.

\section{INTRODUCTION}

Lipases are required for different applications and need to gather adequate biochemical characteristics and be obtained by more ecological processes (Abdallah et al. 2021). Lipases are versatile and mostly used in the food, pharmaceutical and detergent industries and have potential for other purposes such as bioremediation and biofuel production, however, these applications require a high amount of enzymes at low cost (FMI 2018). Lipases of microbial source represent more than $60 \%$ of commercial enzymes, but can also be obtained from animals (about 18\%), plants (approximately 11\%) and algae (3\%) (Bharathi \& Rajalakshmi 2019, Patil et al. 2011). Since lipases can be obtained from different sources, they can have totally different characteristics, differing in the type of catalyzed reaction, affinity for the substrate, $\mathrm{Km}, \mathrm{V}_{\max }$ temperature, $\mathrm{pH}$, organic solvent tolerance, and ultrasonic influence (Bharathi \& Rajalakshmi 2019, Khan et al. 2015, Patil et al. 2011, Seth et al. 2014). Microbial lipases such as those extracted from Candida ssp. are more specific and tolerant to organic solvents, 
therefore, they are the main source of commercial lipases, however their industrial application still have limitations due to the high production cost (Seth et al. 2014, Gupta et al. 2000). Lipases extracted from plants tend to be more stable at acid to basic $\mathrm{pH}$ and temperatures lower than $60^{\circ} \mathrm{C}$, plant lipases usually have high activity in crude extracts, but are more sensitive to organic solvents, so they generally do not maintain high activity after purification processes (Seth et al. 2014). Different lipases could be complementary and have synergistic effect, increasing the resistance of plant enzymes to the presence of solvents, or improving the final transformation by increasing the esterification of fatty acids previously hydrolyzed by other enzymes. In the different applications, the reaction conditions are generally not homogeneous and continuous, since a number of processes may be required for a product production. In food industry, for example, flavor and fragrance can be produced via two processes: esterification and transesterification; lipases can show diverse behaviors in different reaction media, what can be a problem to the large scale production of industrial esters (Sun et al. 2014). Thus, finding a source of lipases that satisfy all the conditions and that is economically feasible can be difficult. Another process that assists the viability of the enzymatic catalysis is the immobilization which, in addition to enable the reuse of enzymes, can provide active sites by removing external interferers, increasing thermal stability and resistance to solvents (Binhayeeding et al. 2020, Tian et al. 2016, Aguieiras et al. 2015). In this context, the present study tested the mixture of fungal and orange lipases, the influence organic solvents and ultrasonic effects on lipase activity, as well, specificity and enzymatic immobilization.

\section{MATERIALS AND METHODS}

\section{Lipases sources and extracts}

The fungal extract was obtained from the strain Aspergillus niger 01 (CBMAI 2084), this microorganism specie was registered under n.A3B348F in the platform of the National Genetic Heritage Management System (SISGEN), as recommended by the Brazilian Biodiversity Law (n. 13.123/15), in the laboratory it is preserved in PDA (Potato Dextrose Agar, KASVI ${ }^{\circledR}$, Italy) slants. All microorganisms were cultivated under solid state fermentation (SSF) using $10 \mathrm{~g}$ of wheat bran moistened with $10 \mathrm{~mL}$ of sterile water and incubated for $120 \mathrm{~h}$ at $30^{\circ} \mathrm{C}$. After this period, we added $50 \mathrm{~mL}$ of deionized water and filtered the suspension through two layers of cotton gauze, the filtrate was considered the crude extract (Fleuri et al. 2014a). The extract showed $68 \mathrm{U} / \mathrm{g}$ lipase in extra virgin olive oil. The enzyme showed stability at alkaline $\mathrm{pH}$ (8.0 to 9.0); optimum temperature peak at $50^{\circ} \mathrm{C}$; affinity for short, medium and long chain substrates ( $p-N P B, p-N P L$ and $p-N P P$ ) and can catalyze reactions of hydrolysis and alcoholysis of vegetable oils, as well as the esterification of oleic acid (Fleuri et al. 2014b).

The plant extract was obtained from the fragment of orange peel (Citrus sinensis L. Osbeck, Pera variety) called frit, a residual fraction generated in JBT Food Tech's in line citrus juice extractor at standard set up. The frit fraction was processed, lyophilized (Liotop ${ }^{\circledR}$ L101) at $-60^{\circ} \mathrm{C}$ for 24 hours and stored at $-20^{\circ} \mathrm{C}$ (Okino-Delgado \& Fleuri 2014). The extract showed $70 \mathrm{U} / \mathrm{g}$ of lipase in extra virgin olive oil. This enzyme showed stability in acid pH (6.0) and two peaks of optimum temperature at 20 and $60^{\circ} \mathrm{C}$. Regarding the substrate affinity, frit lipases were able to catalyze the hydrolysis of long and medium chain ( $p-N P P$ and $p-N P L$ ) substrates (Francisco et al. 2019) as well as the 
hydrolysis and alcoholysis of plant oils, and the esterification of oleic acid (Francisco et al. 2019, Okino-Delgado et al. 2017).

\section{Lipase activity}

Lipase activity was measured by titration method using extra virgin olive oil in an emulsion with arabic gum as substrate (Macedo et al. 1997). The results were expressed in units of lipase activity $(1 \mu \mathrm{mol}$ of fatty acid released per minute under assay conditions). For the determination of lipase specific activity, the concentration of the total proteins in the enzymatic solution was verified by the Biuret method (Gornall et al. 1949). The optimal conditions of temperature and $\mathrm{pH}$ for the activity of fungal $\left(50^{\circ} \mathrm{C}\right.$ and $\left.8-9\right)$ and orange frit lipases $\left(20^{\circ} \mathrm{C}\right.$ and 9$)$ are different so the enzymatic reaction was carry out with the temperature and $\mathrm{pH}$ parameters suggested by the methodology (Macedo et al. 1997).

\section{Synergistic effect}

The synergistic effect of the fungal and orange extracts was delineated in a double factorial arrangement $(5 \times 5)$, with five concentrations of $A$. niger 01 (CBMAI 2084) extract (0, 25, 50,75 and $100 \%$ ) and five concentrations of orange frit extract $(0,25,50,75$ and $100 \%)$ and three replicates. Lipase activity was calculated comparing the theoretical and observed results, this ratio was denominated proportional percentage. When the proportional percentage was greater than $100 \%$, it was considered that there was an increase in enzymatic activity. The enzyme combination that resulted in the highest experimental value observed in relation to the theoretical experimental value and the highest absolute lipase activity was used in the studies of influence of organic solvents and ultrasonic effects on lipase activity, specificity and enzymatic immobilization. In all stages, the isolated extracts and the combination that showed an increase enzymatic activity were tested.

\section{Organic solvents effect}

The organic solvents effect on enzymatic activity was analyzed in a reaction medium similar to the item "Lipase activity" differing only in the addition of solvent to the reaction. Solutions of acetone (P.A., Synth, Brazil), ethanol (P.A., Synth, Brazil) and methanol (P.A., Neon, Brazil) at $30 \%(\mathrm{v} / \mathrm{v})$ were tested. The solvent, enzyme extract and buffer mixture remained at room temperature for $24 \mathrm{~h}$, after this period the lipase activity was measured. The lipase activity without the addition of the solvents was considered $100 \%$ of the relative activity.

\section{Ultrasonic effect}

The ultrasonic effect on enzymatic activity was analyzed in a reaction medium similar to described in item "Lipase activity" differing only in the treatment with 10,20 and 30 s of ultrasonic bath at $50 \mathrm{kHz}$. The mixture of enzyme extract and buffer (boric acid-borax buffer with pH 8.0, $0.1 \mathrm{M}$ ) was subjected to ultrasonic bath, then lipase activity was measured. The activity value without the ultrasonic bath was considered $100 \%$ of the relative activity.

\section{Specificity}

The specificity of the isolated and combined extracts were analyzed on different chains of fatty acids. Lipase activity was measured against different substrates: $p$-nitrophenyl palmitate (p-NPP, C16) (Mahadik et al. 2002) p-nitrophenyl laurate ( $p-N P L, C 12)$ (Gutarra et al. 2009) and p-nitrophenyl butyrate ( $p-N P B, C 4)$ (Calado et al. 2002). All substrates were purchased from Sigma Aldrich ${ }^{\circledR}$ 


\section{Immobilization}

The isolated and combined extracts were immobilized by adsorption and encapsulation. The immobilization by adsorption was tested using celite, silica, aluminum oxide and Lewatti (Sigma Aldrich ${ }^{\circledR}$ ) as supports (Sharma et al. 2008). The supports $(500 \mu \mathrm{g})$ were added to enzyme extract $(1 \mathrm{~mL})$ and shaken at $200 \mathrm{rpm}$ for $1 \mathrm{~h}$ at $20^{\circ} \mathrm{C}$. Then, the mixture passed through filter paper $n^{\circ} .1$ and the supports were washed 3 times with deionized water $(5 \mathrm{~mL})$. The supports were dried at $5^{\circ} \mathrm{C}$ for $24 \mathrm{~h}$. The immobilization by encapsulation was tested using calcium alginate and gelatin methods, with modifications (De Alencar Figueira et al. 2011). The immobilized enzymes, aliquots of $\mathrm{CaCl}_{2}$ solution and the washing and storage buffer were collected for the determination of enzymatic activity and encapsulation efficiency. Lipase activity of immobilized enzymes was analyzed in a reaction medium similar to the item "Lipase activity".

\section{Statistical analysis}

All analysis were performed in triplicate. Data were subject to analysis of variance (ANOVA) and means were compared by Tukey's test ( $p \leq$ 0.01), using the software $\mathrm{R}$ version 3.4.4.

\section{RESULTS AND DISCUSSION}

\section{Mixtures of fungal and plant lipases}

There were differences in lipase activity, between the different concentrations of fungal and orange enzymatic extracts. Data analysis showed that there is significant interaction between factors $(p \leq 0.01)$. In combinations with low concentration (25\%) of fungi and orange extracts lipase activity was low, increasing as the concentration of extracts increased. The relative activity of lipase remained, above $60 \%$, in combinations with more than $25 \%$ of fungal and orange extract. However, above $75 \%$ of fungal extract there were no significant differences, showing that from this point, the increase in activity did not correspond to the increase in the concentration of enzymatic extracts (Table I), and may be due to the saturation of binding sites.

Comparing the theoretical experimental values and the observed experimental values, an increase enzyme activity can be observed in the combination of $25 \%$ fungal extract and $25 \%$ orange extract, corresponding to $223 \%$ proportional activity; in the combination of $50 \%$ fungal extract and 25\% orange extract, corresponding to $155 \%$ proportional activity; and in the combination of $75 \%$ fungal extract and $25 \%$ orange extract, corresponding to $120 \%$ proportional activity. In the combinations with higher concentration (75\%) of orange extract, the observed activity was lower than the theoretical one, indicating that the synergistic effect occurs in low concentration (25\%) of orange extract (Table I).

Although the percentage of proportional activity was higher for the combination of $25 \%$ fungal extract and 25\% orange extract, the actual activity was lower than in the other two combinations that showed an increase of lipase activity. Thus, the combination of $50 \%$ of fungal extract and $25 \%$ of orange extract was selected for further studies. Four lipases (A, B, C and D) from different strains of Aspergillus niger showed different results optimal $\mathrm{pH}$, temperature and specific substrate when analyzed. Lipases B and $D$, with different biochemical characteristics, showed synergism when used together in the hydrolysis of soybean oil, according to Qiao et al. (2017), the synergism occurs due to the specificity in different fatty acids. Lee et al. (2006) verified that Rhizopus oryzae lipase activity was increased by adding the immobilized Candida rugosa lipase, suggesting that nonspecific lipase 
Table I. Effect of fungal and vegetable lipolytic extracts on lipase activity using olive oil as substrate.

\begin{tabular}{|c|c|c|c|c|c|}
\hline Runs & $\begin{array}{l}\text { Fungal extract } \\
(\%)\end{array}$ & $\begin{array}{c}\text { Plant extract } \\
(\%)\end{array}$ & $\begin{array}{l}\text { Lipase activity } \\
(\mathrm{U} / \mathrm{mL})^{*}\end{array}$ & $\begin{array}{c}\% \text { proporcional } \\
\text { to } 25 \mathrm{U}^{* *}\end{array}$ & $\begin{array}{c}\text { Expected / } \\
\text { observed*** }^{*}\end{array}$ \\
\hline 1 & 0 & 0 & 0,00 & $0,00 \mathrm{bc}$ & 0 \\
\hline 2 & 0 & 25 & $3,68 \pm 2,14$ & $14,72 \mathrm{bc}$ & 100.00 \\
\hline 3 & 0 & 50 & $17,13 \pm 2,45$ & $68,50 \mathrm{aB}$ & 100.00 \\
\hline 4 & 0 & 75 & $26,04 \pm 1,42$ & 104,17 aA & 100.00 \\
\hline 5 & 0 & 100 & $24,84 \pm 1,06$ & 99,36 aA & 100.00 \\
\hline 6 & 25 & 0 & $5,24 \pm 1,23$ & 20,94 bB & 100.00 \\
\hline 7 & 25 & 25 & $22,08 \pm 2,12$ & $88,32 \mathrm{aA}$ & 223.26 \\
\hline 8 & 25 & 50 & $17,08 \pm 2,16$ & $68,31 \mathrm{aA}$ & 73.19 \\
\hline 9 & 25 & 75 & $15,64 \pm 1,62$ & $62,56 \mathrm{cA}$ & 48.49 \\
\hline 10 & 25 & 100 & $16,48 \pm 0,85$ & $65,90 \mathrm{bA}$ & 53.06 \\
\hline 11 & 50 & 0 & $27,74 \pm 3,24$ & $110,96 \mathrm{aA}$ & 100.00 \\
\hline 12 & 50 & 25 & $25,10 \pm 0,82$ & $100,40 \mathrm{aAB}$ & 155.90 \\
\hline 13 & 50 & 50 & $14,23 \pm 1,06$ & $56,90 \mathrm{aC}$ & 48.14 \\
\hline 14 & 50 & 75 & $16,48 \pm 2,55$ & $65,90 \mathrm{bcc}$ & 42.83 \\
\hline 15 & 50 & 100 & $20,57 \pm 1,08$ & $82,28 \mathrm{abBC}$ & 55.21 \\
\hline 16 & 75 & 0 & $20,38 \pm 1,42$ & $109,83 \mathrm{aA}$ & 100.00 \\
\hline 17 & 75 & 25 & $26,96 \pm 1,06$ & 99,03 aA & 75.81 \\
\hline 18 & 75 & 50 & $16,76 \pm 1,77$ & $67,03 \mathrm{aB}$ & 46.87 \\
\hline 19 & 75 & 75 & $23,87 \pm 3,34$ & $103,98 \mathrm{aA}$ & 58.19 \\
\hline 20 & 75 & 100 & $26,53 \pm 0,35$ & 93,98 aA & 54.05 \\
\hline 21 & 100 & 0 & $29,44 \pm 4,29$ & 117,76 aA & 100.00 \\
\hline 22 & 100 & 25 & $21,29 \pm 1,96$ & $85,15 \mathrm{aB}$ & 74.64 \\
\hline 23 & 100 & 50 & $20,81 \pm 0,71$ & $83,22 \mathrm{aB}$ & 49.58 \\
\hline 24 & 100 & 75 & $26,33 \pm 0,61$ & $91,55 \mathrm{abAB}$ & 44.98 \\
\hline 25 & 100 & 100 & $24,98 \pm 4,45$ & $107,71 \mathrm{aAB}$ & 54.20 \\
\hline
\end{tabular}

*Average of triplicates followed by standard deviation. ** Lowercase letters compare means in the column with the same color and uppercase letters compare means in the different columns. Means followed by the same letters do not differ statistically by Tukey test $(p \leq 0.01)$. ${ }^{* * *}$ Relation between the values expected (sum of theoretical values based on isolated extracts) and the value observed.

can help 1,3-specific lipase to produce biodiesel by enhancing rate of oil hydrolysis.

\section{Adverse conditions tests}

In order to verify if the combination of $50 \%$ fungal extract and $25 \%$ orange extract maintains its activity under adverse conditions, tests were performed simulating situations common to reaction media of several applications. Isolated extracts were also analyzed for comparison. These tests results are summarized in Figure 1.

Lipase activity decreased in all combinations of extracts and solvents, being lower than the theoretical experimental value and indicating that these lipases are not stable in the tested solvents. There was no increase in lipase activity, 

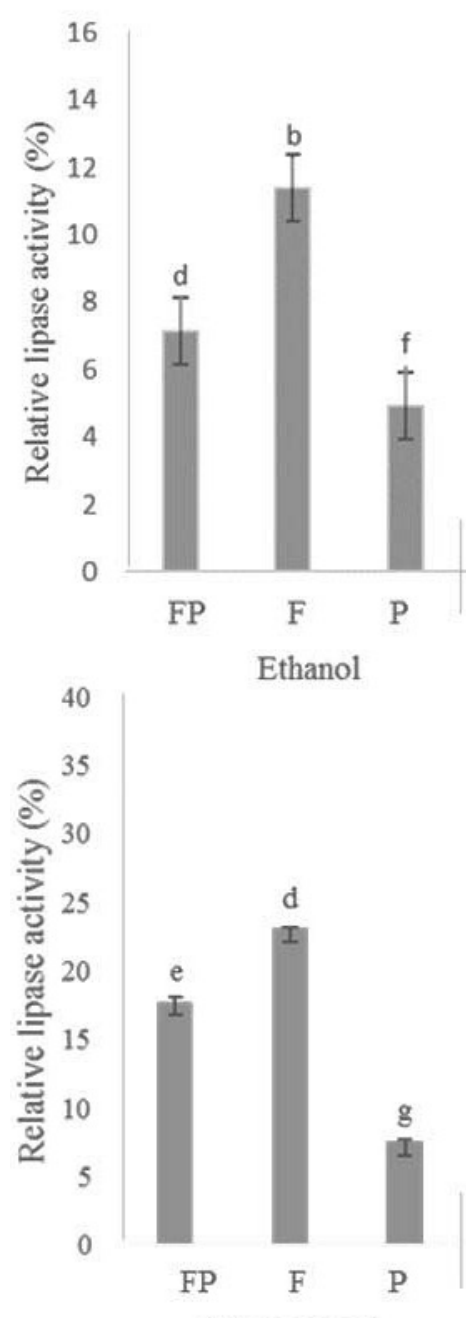

US50kHt 10'
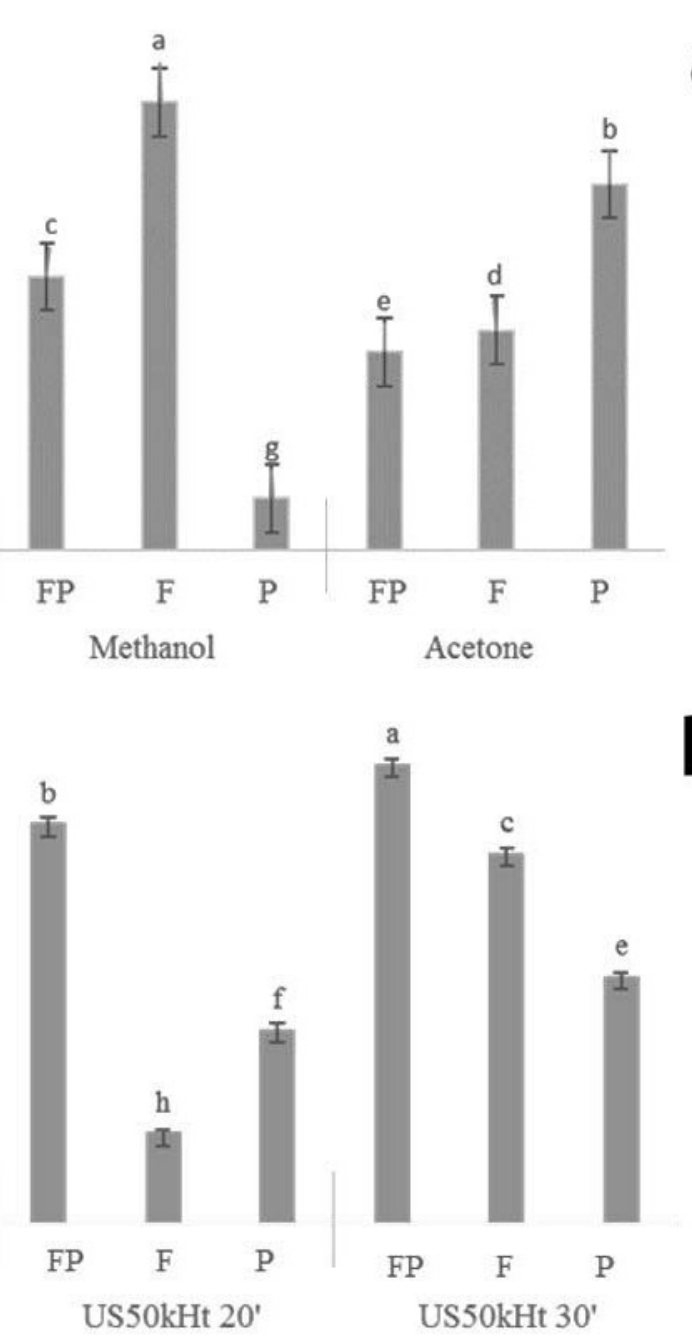

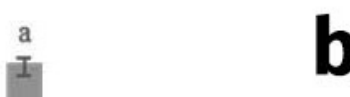

b

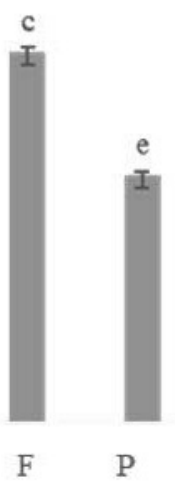

Figure 1. Effect of solvents (a) and ultrasound bath (b) on lipase activity using olive oil and $p-N P B$, p-NPL and $p$-NPP as substrate (c) on isolated and combined fungal and plant extracts ( $F$ - fungal extract; FP - combination of $50 \%$ fungal extract and $25 \%$ plant extract; $P$ - plant extract; p-NPB - p-nitrophenyl butyrate; $\mathrm{p}-\mathrm{NPL}$ p-nitrophenyl laurate; p-NPP - p-nitrophenyl palmitate).

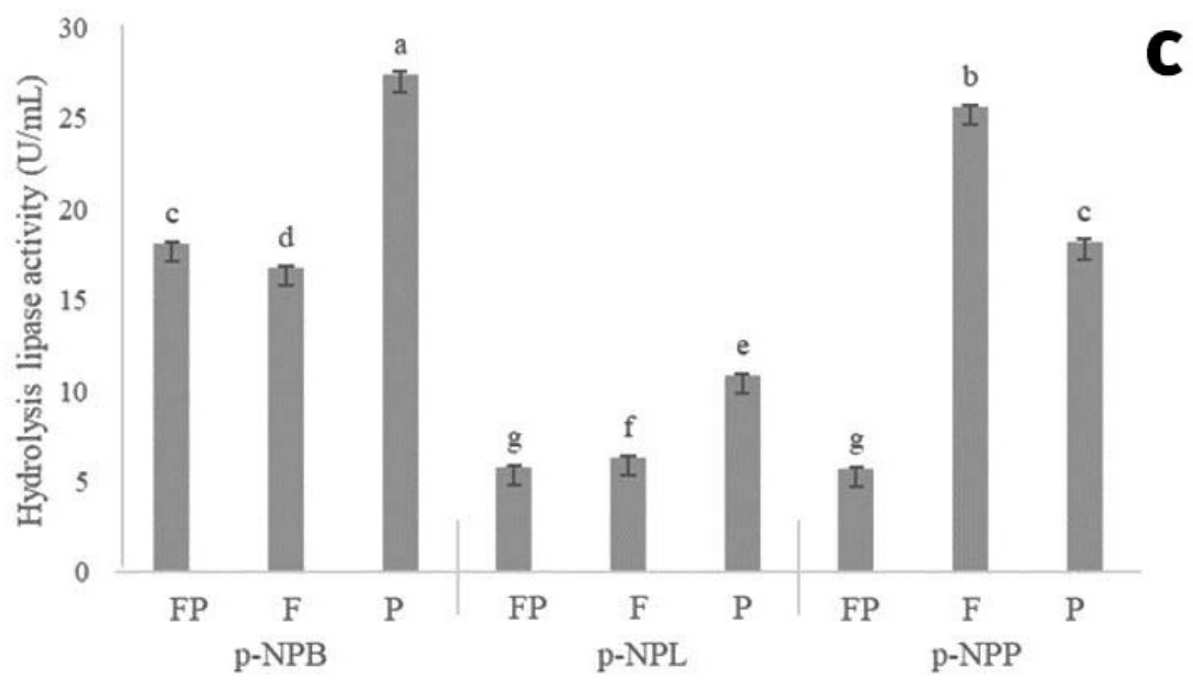

*The same letters do not differ statistically by Tukey test $(p \leq 0.01)$. 
since the activity of the combination of fungal and orange extracts was lower than the isolated extracts for the three tested solvents.

An increase of lipase activity occurred in the treatments after $20 \mathrm{~s}$ of ultrasonic bath, the proportional percentage of activity was higher in the mixture of extracts than in the isolated extracts.

Research carried out with activated sludge, observed the recovery of esterases using lowpower ultrasonic bath and also identified an increase in the activity of esterases directly proportional to the time of exposure to ultrasonic bath (Plattes et al. 2017). While in the study carried out by Karn et al. (2013) a combination of ultrasonic and non-ionic detergent was used to obtain lipases and proteases from activated sludge.

Hydrolysis activity on p-NPP, p-NPB and $p-N P L$ was observed in all combinations of extracts and substrates. The orange extract showed the highest activity in the hydrolysis of the substrates $p-N P B$ and $p-N P L$, while the fungal extract showed the lowest results, and the mixture showed intermediate results indicating that in mixture both extracts maintain lipase activity. On the other hand, the fungal extract showed the highest hydrolysis activity on $\mathrm{p}$-NPP, and the mixture showed lower results than both isolated extracts indicating an antagonistic effect of the lipases in mixture for this substrate.

Lipases tested in this study did not maintain high activity in organic solvents. Lipases have been described, as generally, more unstable in hydrophilic solvents than in hydrophobic ones (Kumar et al. 2016, Klibanov 1990), which limits the application of crude enzymes to other processes using organic solvents, indicating that this crude mixture has higher potential for application in hydrolysis reactions and for synthesis reactions that use low percentage of solvent.
However, the isolated extracts showed different behavior in relation to the solvents: fungal extract maintained the activity of $14 \%$ and $12 \%$ in methanol and ethanol, respectively, higher than orange extract, while orange extract showed higher activity in acetone (10\%) and lower activity in methanol (2\%).

Lipase activity did not completely decrease in the presence of solvents, except for the mixture of extracts in methanol. These results show that these enzymes were not totally unstructured by the solvents and that their activity in the presence of solvents could be increased using analytical strategies that reduce the time of contact between enzyme and solvent or increasing enzyme resistance to the presence of solvents.

In this context, the test of lipase activity after ultrasonic bath indicated that lipases maintained their activity after 20 and $30 \mathrm{~s}$. Thus, this method could be used to improve the reaction system, reducing the time of reaction, temperature and solvent concentration with the same conversion rate, as the hydrolysis of cooking oil waste catalyzed by homemade lipases of Aspergillus niger (Mulinari et al. 2017, Khan et al. 2015). Thus, the use of ultrasonic bath could contribute to reduce lipase sensitivity to organic solvents, since it allows the reduction of solvent proportion in the reaction medium, increasing the interaction between the phases by cavitation and reduction of bubbles, increasing the contact between enzyme and substrate due to the increase of emulsification of the reaction medium and increasing the time of contact with the enzyme by decreasing the reaction time (Mulinari et al. 2017, Martins et al. 2013, Rokhina et al. 2009).

The ultrasonic bath was used to increase the catalytic power of lipases, since, the low ultrasonic frequency (less than $60 \mathrm{kHz}$ ) did not modify the structure of microbial lipases and 
increase the catalytic activity for hydrolysis and synthesis reactions (Zhao et al. 2016). However, as demonstrated in this study, this increase in catalytic power was not verified, since there was a reduction of lipase activity in hydrolysis reaction.

Regarding the specificity for different substrates, there was an increase in hydrolysis of $\mathrm{p}-\mathrm{NPP}$ and $\mathrm{p}-\mathrm{NPL}$, indicating a higher affinity for the hydrolysis of long and medium chain fatty acids. Those data indicate that the mixture of extracts can be applied in the modification of plant oils, which are constituted mainly by triglycerides composed of long chain fatty acids.

\section{Immobilization}

A summary of the immobilized results can be verified in the Figure 2.

Fungal and orange lipases were not efficiently immobilized by encapsulation. The activity of immobilized lipases from orange and fungal extracts by calcium alginate decreased compared to the activity of the initial crude extract. In the first cycle of immobilized lipases activity, the enzymes showed about $15 \%$ of the activity of the initial extract. There was migration of lipases from the alginate solution to the calcium chloride (approximately 35\% of relative activity). Thus, it was verified that calcium alginate fixed a small percentage of lipases. However, the immobilized fungal lipases maintained their activity. In the first cycle approximately $25 \%$ of relative activity was maintained and in the second cycle approximately $15 \%$ of relative activity was maintained, showing that after retention in calcium alginate the lipases remained immobilized and active. Lipase activity in extracts immobilized by gelatin also decreased significantly compared to the activity of the crude extract, in the first cycle of activity, immobilized lipases showed about $15 \%$ of the activity of the initial fungal extract,
$19 \%$ for orange and $20 \%$ for the mixture. The migration of lipases from the gelatin solution to glutaraldehyde (approximately $50 \%$ of relative activity) was observed. We concluded that the chosen techniques do not efficiently retain the lipases tested but maintain lipase activity.

Isolated orange and fungal extracts maintained more than $40 \%$ of the lipase activity when immobilized by celite, silica and Lewatti, while the mixture of extracts showed better results in celite and silica, above $60 \%$ of the initial activity. The support that showed the best performance for immobilization of all extracts tested was silica, maintaining up to $85 \%$ of the activity compared to the crude orange extract. Therefore, we concluded that immobilization by adsorption is the most appropriate method for lipases immobilization in the tested extracts, mainly using silica as support, which was able to maintain activity about 4-fold than in encapsulation techniques, indicating that the enzymes tested require interaction with the support for immobilization.

Enzymatic immobilization increases the stability of enzymes due to the protection against the action of solvents, changes in $\mathrm{pH}$ and temperature (An et al. 2015, Chiou et al. 2007). Moreover, it is possible to reuse the enzymes after the reaction. However, in general, the enzymes have disadvantages such as a high decrease in activity due to the blocked enzyme active site, restriction of flexibility and limitation of mass transfer between enzyme and substrate (Datta et al. 2012). Therefore, developing the appropriate method is indispensable to ensure its advantages while maintaining high enzyme activity.

The encapsulation is a physical technique of immobilization which consists of confining the enzymes in insoluble polymers, not involving chemical interactions between enzyme and support, but limiting mass transfer, since the 


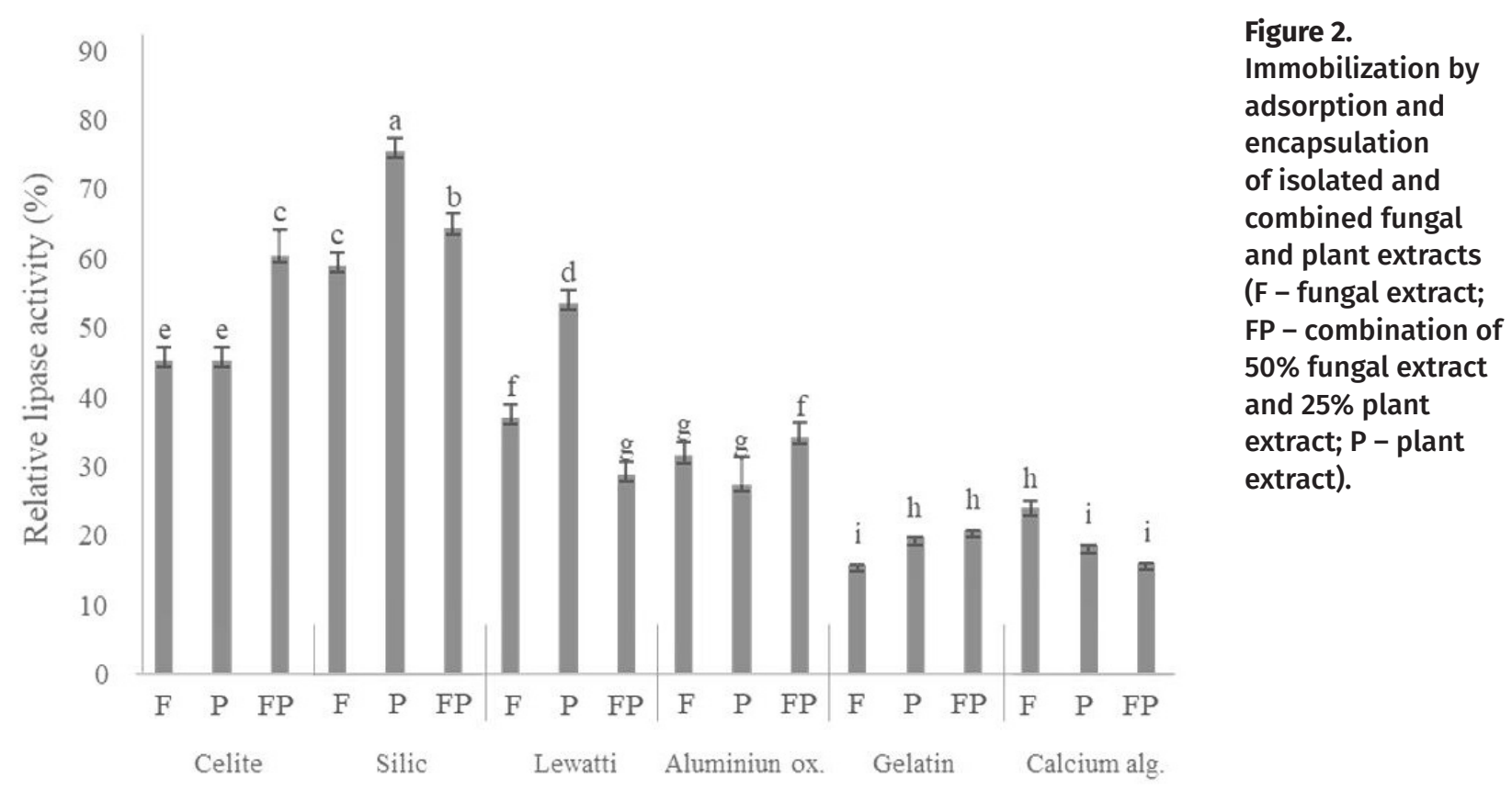

*The same letters do not differ statistically by Tukey test $(p \leq 0.01)$.

contact between enzyme and substrate depends on the diffusion rate of the substrate in the polymer used to trap the enzyme (Falkeborg et al. 2015). The lipases tested in this study showed low performance with encapsulation techniques using gelatin and alginate as support. Lipases showed high rates of reuse and stability, but in comparison to the crude extracts, there was a marked decrease in enzymatic activity (Toscano et al. 2014). Thus, due to the low performance of lipases immobilized by encapsulation, we concluded that this technique does not efficiently retain the lipases tested, but the retained lipases maintain the activity.

Adsorbent immobilization techniques involve chemical interactions between the enzyme and adsorbent, with different types of chemical interactions, such as van der Waals forces, hydrogen bonds, hydrophobic interactions and covalent bonds (An et al. 2015). The covalent bond immobilization test performed with aluminum oxide showed a relative lipase activity of 30 to $35 \%$ in the fungal, plant and combined extracts. In the literature, other lipases obtained higher percentages of activity for immobilizations with chemical interaction. Pig pancreas lipases immobilized on covalent magnetic microspheres achieved $63 \%$ of activity (Lei et al. 2009), while microbial lipases immobilized for covalent binding method on epoxy resin obtained $79 \%$ of activity (Li et al. 2016b). Recent studies have shown that the porosity of the materials used as support is among the factors of greater influence on the activity of the immobilized enzymes, since they directly influence the mass transfer capacity. The lipases tested in this study showed promising results for silica and celite maintaining 75 to $60 \%$ of lipase activity and corroborating previous study results (Li et al. 2016a, Chang et al. 2007), those results can be explained due to the macro and mesoporosity of the materials, allowing the rapid transfer of mass. Lewatti, which has high microporosity, showed 50 to $30 \%$ lipase activity. In addition, celite and silica are inert, non-toxic and low-cost materials; consequently, they can 
be considered suitable materials to support the immobilization of the tested enzymes and could be used in the most diverse areas such as food industry, pharmaceutical, biodiesel, among others. In this case, we proposed some of the relevant criteria in lipase activity, from these results, others parameters can be considered in future analysis (Sagiroglu and Arabaci 2005).

\section{CONCLUSIONS}

The lipases tested were influenced by all reactional conditions. Lipases produced by Aspergillus niger 01 (CBMAI 2084) and orange frit can hydrolyze fatty acid of different chain lengths. The produced lipases can be used isolated or combined, free or immobilized by adsorption. The most efficient formulations are mixes with higher concentration of fungal extract, which also favors the reaction medium resistance to changes. However, the combination of lipases from different sources demonstrated that the mixture does not affect the individual activity of lipases from plant and fungal sources for most of the evaluated parameters. Among the tested materials, silica showed the best results for lipase immobilization, which suggests that the immobilization performance is directly proportional to the macropore volume. The results show the biotechnological potential of these lipases for further studies and applications.

\section{Acknowledgments}

The authors thank the Fundação de Amparo à Pesquisa do Estado de São Paulo (FAPESP) no 2014/10962-7 and no 2015/017503-9, the Dean of Research of UNESP for the grants and scholarships awarded and to JBT Food Tech for orange waste. This study was financed in part by the Coordenação de Aperfeiçoamento de Pessoal de Nivel Superior - Brasil (CAPES) - Finance Code 001.

\section{REFERENCES}

ABDALLAH RI, HAMDY K \& KWANG-HYUN B. 2021. Temperatureresistant and solvent-tolerant lipases as industrial biocatalysts: Biotechnological approaches and applications. Int J Biol Macromol 187: 127-142.

AGUIEIRAS ECG, CAVALCANTI-OLIVEIRA ED \& FREIRE DMG. 2015. Current status and new developments of biodiesel production using fungal lipases. Fuel 159: 52-67.

AN N, ZHOU CH, ZHUANG XY, TONG DX \& YU WH. 2015. Immobilization of enzymes on clayminerals for biocatalysts and biosensors. Appl Clay Sci 114: 283-296.

BHARATHI D \& RAJALAKSHMI G. 2019. Microbial lipases: An overview of screening, production and purification. Biocatal Agric Biotechnol 22: 101368.

BINHAYEEDING N, YUNU T, PICHID N, KLOMKLAO S \& SANGKHARAK K. 2020. Immobilisation of Candida rugosa lipase on polyhydroxybutyrate via a combination of adsorption and cross-linking agents to enhance acylglycerol production. Process Biochem 0-1.

CALADO C, MONTEIRO SMS, CABRAL JMS \& FONSECA LP. 2002. Effect of pre-fermentation on the production of cutinase by a recombinant Saccharomyces cerevisiae. J Biosci Bioeng 93: 354-359.

CHANG SF, CHANG SW, YEN YH \& SHIEH CJ. 2007. Optimum immobilization of Candida rugosa lipase on Celite by RSM. Appl Clay Sci 37: 67-73.

CHIOU SH, HUNG TC, GIRIDHAR R \& WU WT. 2007. Immobilization of lipase to chitosan beads using a natural cross-linker. Prep Biochem Biotechnol 37: 265-275.

DATTA S, CHRISTENA LR \& RAJARAM YRS. 2012. Enzyme immobilization: an overview on techniques and support materials. 3 Biotech 3: 1-9.

DE ALENCAR FIGUEIRA J, DIAS FFG, SATO HH \& FERNANDES P. 2011. Screening of supports for the immobilization of $\beta$-glucosidase. Enzyme Res 2011: 1-8.

FALKEBORG M, PAITAIDA P, SHU AN, PÉREZ B \& GUO Z. 2015. Dodecenyl succinylated alginate as a novel material for encapsulation and hyperactivation of lipases. Carbohydr Polym 133: 194-202.

FLEURI LF, DE OLIVEIRA MC, ARCURI MLC, CAPOVILLE BL, PEREIRA MS, DELGADO, CHO \& NOVELLI PK. 2014a. Production of fungal lipases using wheat bran and soybean bran and incorporation of sugarcane bagasse as a co-substrate in solid-state fermentation. Food Sci Biotechnol 23: 1199-1205. 
FLEURI LF, NOVELLI PK, DELGADO CHO, PIVETTA MR, PEREIRA MS, ARCURI MLC \& CAPOVILLE BL. 2014b. Biochemical characterisation and application of lipases produced by Aspergillus sp. on solid-state fermentation using three substrates. Int J Food Sci Technol 49: 2585-2591.

FMI - FUTURE MARKET INSIGHTS. 2018. Lipase Market: Food Application to Dominate the Global Market in Terms of Revenue: Global Industry Analysis (2012-2016) and Opportunity Assessment (2017-2026). Available in: https://www.futuremarketinsights.com/reports/lipasemarket. Accessed in April 2020.

FRANCISCO VCB, OKINO-DELGADO CH, ZANUTTO ELGUI MR, FERNANDES CJC, FACANALI R, SILVA RA, ZAMBUZZI WF, MARQUES MOM \& FLEURI LF. 2019. Plant oil bioconversion into increase biological activity through lipases derived from wastes. Int J Food Sci Technol 54: 1089-1099.

GORNALL AG, BARDAWILL CJ \& DAVID MM. 1949. Determination of serum proteins by means of the biuret reaction. J Biol Chem 177: 751-766.

GUPTA AK, SINGH AK, BHATIA RB \& BRINKER CJ. 2000. Aqueous Sol-Gel Process for protein encapsulation. Chem Mater 12: 24-34.

GUTARRA MLE, GODOY MG, MAUGERI F, RODRIGUES MI, FREIRE DMG \& CASTILHO LR. 2009. Production of an acidic and thermostable lipase of the mesophilic fungus Penicillium simplicissimum by solid-state fermentation. Bioresour Technol 100: 5249-5254.

KARN SK, KUMAR P \& PAN X. 2013. Extraction of lipase and protease and characterization of activated sludge from pulp and paper industry. Prep Biochem Biotechnol 43: 152-162.

KHAN NR, JADHAV SV \& RATHOD VK. 2015. Lipase catalysed synthesis of cetyl oleate using ultrasound: optimisation and kinetic studies. Ultrason Sonochem 27: 522-529.

KLIBANOV AM. 1990. Asymmetric transformations catalyzed by enzymes in organic solvents. Acc Chem Res 23: 114-120.

KUMAR A, DHAR K, KANWAR SS \& ARORA PK. 2016. Lipase catalysis in organic solvents: advantages and applications. Biol Proced Online 18: 1-11.

LEE DH, KIM JM, SHIN HY, KANG SW \& KIM SW. 2006. Biodiesel Production Using a Mixture of Immobilized Rhizopus oryzae and Candida rugosa Lipases. Biotechnol Bioprocess Eng 11: 522-525.

LEI L, BAI Y, LI Y, YI L, YANG Y \& XIA C. 2009. Study on immobilization of lipase onto magnetic microspheres with epoxy groups. J Magn Magn Mater 321: 252-258.
LI J, LI LS \& XU L. 2016a. Hierarchically macro/mesoporous silica sphere: A high efficient carrier for enzyme immobilization. Microp and Mesop Mater 231: 147-153.

LI X, LI D, WANG W, DURRANI R, YANG Y \& WANG Y. 2016b. Immobilization of SMG1-F278N lipase onto a novel epoxy resin: Characterization and its application in synthesis of partial glycerides. J Mol Catal B Enzym 133: 154-160.

MACEDO GA, PASTORE GM \& PARK YK. 1997. Partial purification and characterization of an extracellular lipase from a newly isolated strain of Geotrichum sp. Brazilian J Microbiol 28: 90-98.

MAHADIK ND, PUTAMBEKAR US, BASTAWDE KB, KHIRE JM \& GOKHALE D. 2002. Production of acidic lipase by Aspergillus niger in solid state fermentation. Process Biochem 38: 715-721.

MARTINS AB, SCHEIN MF, FRIEDRICH JLR, FERNANDEZ-LAFUENTE R, AYUB MAZ \& RODRIGUES RC. 2013. Ultrasound-assisted butyl acetate synthesis catalyzed by Novozym 435: Enhanced activity and operational stability. Ultrason Sonochem 20: 1155-1160.

MULINARI J ET AL. 2017. Ultrasound-assisted hydrolysis of waste cooking oil catalyzed by homemade lipases. Ultrason Sonochem 35: 313-318.

OKINO-DELGADO CH, DO PRADO DZ, FACANALI R, MARQUES MOM, NASCIMENTO AS, FERNANDES CJC, ZAMBUZZI WF \& FLEURI LF. 2017. Bioremediation of cooking oil waste using lipases from wastes. PLoS One 12: 1-17.

OKINO-DELGADO CH \& FLEURI LF. 2014. Obtaining lipases from byproducts of orange juice processing. Food Chem 163: 103-107.

PATIL KJ, CHOPDA MZ \& MAHAJAN RT. 2011. Lipase biodiversity. Indian J Sci Technol 4: 971-982.

PLATTES M, KOEHLER C \& GALLÉ T. 2017. Purely ultrasonic enzyme extraction from activated sludge in an ultrasonic cleaning bath. MethodsX 4: 214-217.

QIAO H, ZHANG F, GUAN W, ZUO J \& FENG D. 2017. Optimisation of combi-lipases from Aspergillus niger for the synergistic and efficient hydrolysis of soybean oil. Anim Sci J 88: 772-780.

ROKHINA EV, LENS P \& VIRKUTYLE J. 2009. Low-frequency ultrasound in biotechnology: state of the art. Trends Biotechnol 27: 298-306.

SAGIROGLU A \& ARABACI N. 2005. Sunflower seed lipase: Extraction, purification, and characterization. Prep Biochem Biotechnol 35: 37-51. 
SETH S, CHAKRAVORTY D, DUBEY VK \& PATRA S. 2014. An insight into plant lipase research - challenges encountered. Protein Expr Purif 95: 13-21.

SHARMA S, AGARWAL L \& SAXENA RK. 2008. Purification, immobilization and characterization of tannase from Penicillium variable. Bioresour Technol 99: 2544-2551.

SUN J, LEE LWW \& LIU SQ. 2014. Biosynthesis of FlavourActive Esters via Lipase-Mediated Reactions and Mechanisms. Aust J Chem 67: 1373-1381.

TIAN X, DAI L, LIU M, LIU D, DU W \& WU H. 2016. Lipasecatalyzed methanolysis of microalgae oil for biodiesel production and PUFAs concentration. Catal Commun 84: 44-47.

TOSCANO L, MONTERO G, STOYTCHEVA M, CERVANTES L \& GOCHEV V. 2014. Comparison of the performances of four hydrophilic polymers as supports for lipase immobilisation. Biotechnol Biotechnol Equip 28: 52-60.

ZHAO X, BANSODE SR, RIBEIRO A, ABREU AS, OLIVEIRA C, PARPOT P, GOGATE PR, RATHOD VK \& CAVACO-PAULO A. 2016. Ultrasound enhances lipase-catalyzed synthesis of poly (ethylene glutarate). Ultrason Sonochem 31: 506-511.

\section{How to cite}

OKINO-DELGADO CH, PEREIRA MS, PRADO DZ \& FLEURI LF. 2022 Evaluation of the influence of chemical and physical factors on mixtures of fungal and plant lipases. An Acad Bras Cienc 94: e20201268. DOI 10.1590/00013765202220201268.

Manuscript received on August 10, 2020;

accepted for publication on November 26, 2020

\section{CLARISSA H. OKINO-DELGADO}

https://orcid.org/0000-0002-8750-7298

\section{MILENE STEFANI PEREIRA}

https://orcid.org/0000-0003-0545-5509

\section{DÉBORA Z. DO PRADO}

https://orcid.org/0000-0001-9731-103X

\section{LUCIANA FRANCISCO FLEURI}

https://orcid.org/0000-0002-0438-2478

São Paulo State University (UNESP), Department of Chemical and Biological Sciences, Bioscience Institute, Prof. Dr. Antônio Celso Wagner Zanin, 250, Distrito de Rubião Junior, 18618-000 Botucatu, SP, Brazil

Correspondence to: Luciana Francisco Fleuri

E-mail: luciana.fleuri@unesp.br

\section{Author contributions}

The authors are part of the same research group. Clarissa Hamaio Okino-Delgado conceived and developed the study worked in programming and carrying out the experiments and developed the text. Milene Stefani Pereira contributed with the knowledge of lipases and the development and formation of the text. Débora Zanoni do Prado contributed to the development of the text, its translation and statistical analysis of the results. Luciana Francisco Fleuri is coordinator and advisor of the research group - she participated, supervised, corrected and directed all stages of the development of the project and this article.

\section{(cc) BY}

